\author{
KS. MICHAŁ KŁAKUS* - TOULON (FRANCJA)
}

KS. JERZY MYSZOR** - KATOWICE

\title{
KAPELANI WOJSKA POLSKIEGO W OFLAGU \\ W ROTENBURGU (XII 1939 - IV 1940) \\ - HISTORIA JEDNEJ FOTOGRAFII
}

\begin{abstract}
Streszczenie
Autorzy na podstawie zbiorowej fotografii wykonanej w Rotenburgu datowanej na początek 1940 r. identyfikują i przedstawiają życiorysy wojenne grupy 57 kapelanów Wojska Polskiego: jeńców oflagu w Rotenburgu nad Fuldą, następnie więźniów obozu koncentracyjnego w Buchenwaldzie i Dachau.
\end{abstract}

Słowa kluczowe: kapelani wojskowi; jeńcy wojenni; więźniowie obozów koncentracyjnych; Rotenburg an der Fulda; Dachau

$* * * * *$

Materiały z Ordynariatu Biskupa Polowego Wojska Polskiego Józefa Gawliny przechowywane w Archiwum Polskiej Misji Katolickiej w Anglii i Walii dostarczają wielu interesujących, a nieznanych dotychczas informacji na temat organizacji duszpasterstwa wojskowego w czasie II wojny światowej ${ }^{1}$. Zawierają one unikalny materiał poznawczy dotyczący losów polskich kapelanów wojskowych. Oprócz źródeł pisanych w archiwum zachowały się również rzadkie, dotychczas nieznane fotografie dokumentujące losy kapelanów Wojska Polskiego w czasie II wojny światowej. Jedną z nich jest fotografia przedstawiająca grupę polskich kapelanów wojskowych - uczestników kampanii wrześniowej w 1939 r. Na foto-

* Ks. Michał Kłakus - dr historii Kościoła; Institut Diocésain de Formation Pastorale Toulon e-mail:mklakus@gmail.com

https://orcid.org/0000-0002-0012-7525

** Ks. Jerzy Myszor - prof. dr hab nauk humanistycznych, Wydział Teologiczny, Uniwersytet Śląski w Katowicach

e-mail: jerzy.myszor@us.edu.pl

https://orcid.org/0000-0003-2792-2956

${ }^{1}$ J. Kowalska, Ordynariat biskupa Polowego Wojska Polskiego w Archiwum Polskiej misji Katolickiej w Anglii i Walii, w: Arcybiskup Józef Gawlina. Biskup polowy wojska Polskiego, red. A. Siomkajło, Londyn 2015, s. 33-42. 
grafii widnieje 57 z 59 kapelanów, którzy zostali wywiezieni pod koniec 1939 r. do niemieckiego obozu jenieckiego w Rotenburgu ${ }^{2}$ (oflag IX C) ${ }^{3}$.

Przed 1940 r. pojmanych pod różnymi pretekstami duchownych polskich, tzw. świeckich, kierowano do różnych obozów koncentracyjnych. Duchownych będących kapelanami wojskowymi traktowano początkowo na równi z kadrą oficerską $\mathrm{i}$ internowano $\mathrm{w}$ tzw. oflagach razem $\mathrm{z}$ innymi oficerami. Kapelanów polskiej armii zgrupowano w Rotenburgu. W kwietniu 1940 r. zostali oni przeniesieni najpierw do Buchenwaldu, a następnie do Dachau (7 lipca 1942 r.) i odtąd byli traktowani jak pozostali więźniowie obozu koncentracyjnego ${ }^{4}$.

Zgodnie z relacją ks. Artura Rojka, właściciela fotografii, w obozie Rotenburg/Fulda znajdowało się 59 księży - w tym: 19 kapelanów służby stałej, 30 rezerwy i 10 - księży świeckich ${ }^{5}$. Identyczne zdjęcie (lecz wykadrowane, bez podpisu i z widocznymi ubytkami) można znaleźć na stronie internetowej prowadzonej przez Heinricha Nuhna ${ }^{6}$. Fotografia przedstawiająca kapelanów wojskowych w Rotenburgu została wykonana zapewne w większej liczbie egzemplarzy z przeznaczeniem dla wszystkich na niej widniejących księży, w tym jedna z nich znalazła się w zbiorach ks. Rojka. Do fotografii dołączył on spis księży-kapelanów przebywających w oflagu w Rotenburgu wraz z lakonicznymi informacjami na temat ich biografii ${ }^{7}$. W tej samej kolekcji znajduje się kilkustronicowe osobiste świadectwo ks. Rojka zawierające opis przeżyć kapelanów wojennych od czasu kapitulacji II Rzeczypospolitej do momentu wyzwolenia obozu w Dachau w 1945 r. Oba dokumenty (opis zdjęcia) oraz opis przeżyć zostały sporządzone na prośbę gen. Stanisława Kopańskiego ${ }^{8}$ oraz za wiedzą i poparciem biskupa polowego Józefa Gawliny, od 1949 r. Protektora Polskiej Emigracji na świecie, który po wojnie zlecił ks. Bronisławowi Michalskiemu $u^{9}$ przygotowanie historii duszpa-

${ }^{2}$ Niem. Rotenburg an der Fulda.

${ }^{3}$ Archiwum Polskiej Misji Katolickiej w Anglii i Walii w Londynie, Ordynariat Biskupa Polowego Wojska Polskiego, Duszpasterstwo polskie w Niemczech, Księża polscy w obozach jenieckich, (dalej: APMAW), A. Rojek, Fotografia Ks. Kapelanów Kampanii Wrześniowej 1939 roku według szeregów, licząc od strony lewej, Londyn 29 II 1948.

${ }^{4}$ J. Woś, W. Jacewicz, Martyrologium polskiego duchowieństwa rzymskokatolickiego pod okupacja hitlerowska w latach 1939-1945, z. 1-4, Warszawa 1977-1978, (dalej: Martyrologium).

${ }^{5}$ APMAW, Ordynariat Biskupa Polowego Wojska Polskiego, Duszpasterstwo polskie w Niemczech, Księża polscy w obozach jenieckich. Rojek do Kopańskiego, Londyn 29 II 1948.

${ }^{6}$ Heinrich Nuhn (1938-), niemiecki historyk, kustosz muzeum żydowskiego; https://hinterstacheldraht.jimdofree.com/polen/polnische-feldgeistliche/56-auf-gruppenfoto/ (dostęp: 10.11.2020).

${ }^{7} \mathrm{O}$ znaczeniu fotografii w badaniach historycznych zob. A. Barzycka-Paździor, Fotografia jako źródto historyczne: wybrane problemy, „Historyka: Studia Metodologiczne”, 36 (2006) s. 105-117.

${ }^{8}$ Stanisław Kopański (1895-1976), gen. dywizji, od kwietnia 1940 r. dowódca Brygady Strzelców Karpackich w Syrii w ramach francuskiej Armii Lewantu, uczestnik kampanii północnoafrykańskiej 1941-1942 (Tobruk, Bardia, El Gazala), w 1942 r. dowódca 3 DSK, szef Sztabu Naczelnego Wodza (1943-1947), główny Inspektor Polskiego Korpusu Przysposobienia i Rozmieszczenia

${ }^{9}$ Ks. Bronisław Michalski (1892-1968), kapelan WP (1918), wraz z bp. J. Gawliną opuścił kraj (1939), wikariusz generalny Kurii Polowej WP (1941). 
sterstwa $\mathrm{z}$ okresu II wojny światowej ${ }^{10} \mathrm{i}$ zachęcał polskich kapelanów do spisywania przeżyć wojennych celem przygotowania historii duszpasterstwa w tamtym czasie $^{11}$. Zdjęcie wykonano w pochmurny i suchy (brak widocznych śladów śniegu) dzień. Jedynie kilku księży próbuje zachować pogodny wyraz twarzy. Zdecydowana większość patrzy w obiektyw z rezerwą i nieufnością. Do drugiego egzemplarza fotografii dotarł niemiecki historyk Nuhn i zamieścił go na swojej stronie internetowej.

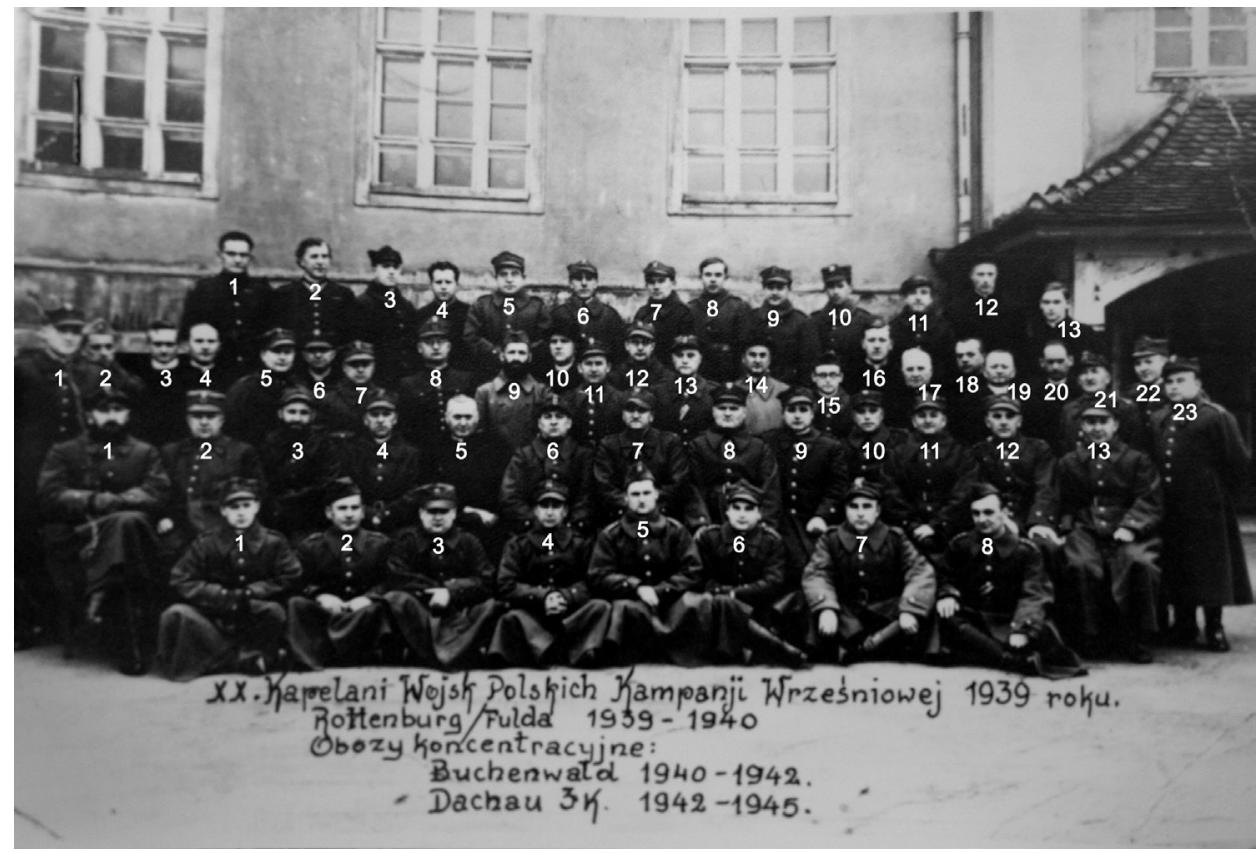

Il. 1. Kapelani Wojsk Polskich Kampanii Wrześniowej 1939 r.

Źródło: APMAW, Londyn, Ordynariat Biskupa Polowego Wojska Polskiego, Duszpasterstwo polskie w Niemczech, Księża polscy w obozach jenieckich.

Opis fotografii przygotowany przez ks. Rojka i Nuhna zawiera w większości przypadków podstawowe dane personalne: imię i nazwisko, datę i miejsce urodzenia i śmierci (Nuhn), stopień wojskowy, przynależność kościelną (Rojek), datę opuszczenia obozu (Nuhn), miejsce pobytu w 1948 r. (Rojek). Wspomniane opisy nie są jednak pozbawione luk, błędów i nieścisłości, takich jak: brak danych

${ }^{10}$ APMAW, Duszpasterstwo polskie w Niemczech, Księża polscy w obozach jenieckich, Michalski do Bombasa, Londyn 12 IV 1951.

${ }^{11} \mathrm{~W}$ zbiorach Ordynariatu można znaleźć kilkadziesiąt świadectw polskich kapelanów, którzy już w 1945 r. odpowiedzieli na apel biskupa polowego. Oficjalnie w 1953 r. w „Duszpasterzu Polskim Zagranicą" ukazała się odezwa do dalszego przekazywania tych informacji. Zob. Apel do Księży bytych Kapelanów Wojska Polskiego w sprawie pomocy do opracowania Historii Duszpasterstwa w P.S.Z. podczas Drugiej Wojny Światowej 1939-1945, „Duszpasterz Polski Zagranicą”, IV-VI (1953) nr 2, s. 121-124. 
personalnych wynikających z niepamięci ks. Rojka w przypadku sześciu duchownych, błędne podanie imion (Nuhn) ${ }^{12}$. Niepotwierdzone informacje w wykazie ks. Rojka, błędy w datach śmierci wynikają prawdopodobnie $\mathrm{z}$ tego, że autor przygotowując opis na początku 1948 r., nie był w stanie przypomnieć sobie pewnych wydarzeń z ,obozowej przeszłości” oraz nie posiadał pełnej wiedzy o losach kapelanów z Rotenburga. Spis przygotowany przez Nuhna zawiera liczne błędy językowe (brak polskich znaków, zamiany liter).

Jak już wspomniano, zdjęcie przedstawia 57 księży: 45 w mundurze wojskowym oraz 12 w sutannach. Dwóch z nich (Szerlągowski, Gałat) w czasie aresztowania pełnili służbę jako kapelani w szpitalu polowym co - być może - tłumaczy brak umundurowania wojskowego. Pozostałych (Bączkowski, Bujak, Góralik, Hübner, Kańtoch, Klarzak, Konrad, Laboń, Maciejiszek, Pawłowski), ks. Rojek (sugerując się prawdopodobnie ubraniem, które nosili) opisywał jako proboszczów lub wikariuszy cywilnych. W rzeczywistości (prócz Bączyńskiego, Hübnera, Labonia, Pawłowskiego) byli to kapelani rezerwy lub byli duchowni wojskowi. W kilku przypadkach niemieckie wojsko potraktowało duchownego parafialnego jako kapelana wojskowego, gdyż znaleziono przy nim dowody świadczące o tym, że był kapelanem rezerwy. Ks. Augustyn Kańtocha, kapelan rezerwy, miał się stawić w dowództwie 27 Pułku Piechoty 3 września 1939 r., jednak już 1 września w godzinach wieczornych został zatrzymany przez Wehrmacht. Niemcy znaleźli na plebanii jego mundur wojskowy i broń. Ks. Józef Klarzak, został zatrzymany 3 września. Znaleziono przy nim dokumenty świadczące o tym, że był kapelanem rezerwy Wojska Polskiego ${ }^{13}$.

W swoim opracowaniach zarówno Rojek, jak i Nuhn wspominają jeszcze o dwóch księżach, którzy byli jeńcami w Rotenburgu, lecz z nieznanych przyczyn nie znaleźli się na zdjęciu. Na fotografii brakuje ks. Edwarda Szabelskiego ${ }^{14}$, który był jeńcem w Rotenburgu od grudnia 1939 r. Ks. Rojek przypomina, że brakuje na nim także ks. Bolesława Trussa ${ }^{15}$, który również był jeńcem w Rotenburgu.

Najstarszymi w grupie byli ks. Feliks Pawłowski (ur. 1875) oraz ks. Jan Bączyński (ur. 1882), którzy w czasie przebywania w Rotenburgu skończyli odpo-

${ }^{12}$ Ks. Andrzej Kamiński a nie „Kazimierz”; ks. Janusz Juliusz a nie „Julian”.

${ }^{13}$ W.P. Wlaźlak, Duszpasterstwo wojskowe w diecezji częstochowskiej, „Ziemia Częstochowska", 32 (2005) s. 1-19.

${ }^{14}$ Edward Szabelski (1898-1942), kap. 135 pp, jeniec w Arnswalde i Rotenburgu (od grudnia 1939 r.), więzień w Buchenwaldzie (18 kwietnia 1940 r.) i Dachau (7 lipca 1942 r.), gdzie zm. 6 sierpnia 1942 r. S. Podlewski, Wierni Bogu i Ojczyźnie. Duchowieństwo katolickie w walce o niepodległość Polski w II wojnie światowej, Warszawa 1985, s. 282, Według Weilera zm. 6 sierpnia 1942 r.. E. Weiler, Die Geistlichen in Dachau sowie in anderen Konzentrationslagern und in Gefängnissen. Nachlaß von Pfarrer Emil Thoma. Erweitert und herausgegeben von Pfarrer E. Weiler, Mödling [1971], s. 650; Martyrologium z. 3, s. 276.

${ }^{15}$ Bolesław Cyriak Truss (1890-1942), duszpasterz w parafii wojskowej w Dęblinie, dziekan w Armii „Kraków”, jeniec w Murnau, Rotenburgu, więzień w Buchenwaldzie (18 kwietnia 1940) i Dachau (7 lipca 1942), gdzie zm. 12 lipca 1942 r. G. Zeller, La Baraque des prêtres, Dachau 19381945, Paris 2015, s. 117; J.W. Wysocki (red.), Kapelani wrześniowi: służba duszpasterska w Wojsku Polskim w 1939 r.: dokumenty, relacje, opracowania, Warszawa 2001, s. 538, 636; Weiler, Die Geistlichen, s. 672, Podlewski, Wierni Bogu, s. 278. 
wiednio 64 i 57 lat. Co więcej, obaj doczekali kapitulacji III Rzeszy. Przed uwięzieniem dobrze się znali, gdyż obaj mieszkali w Krościenku (pierwszy jako emeryt, a drugi jako proboszcz parafii). Nieprzypadkowo więc na zdjęciu widać ich stojących obok siebie. Najstarszym kapelanem wojskowym w czynnej służbie był ks. Jerzy Szacki urodzony w 1884 r. (miał 55 lat). Najmłodszymi byli ks. wikary z Podwilka Henryk Hübner (ur. w 1913), liczący 26 lat, oraz kapelan 14 Pułku Piechoty ks. Józef Gołąb, urodzony w 1911 r. Pierwszy z nich widoczny jest na zdjęciu obok swego proboszcza z Podwilka, ks. Góralika, aresztowanego w tym samym czasie.

Nieprzypadkowo również na centralnym miejscu (drugi rząd w centrum) usiedli księża Kamiński, Tomiak i Dymarski, którzy zostali wyznaczeni przez kapelanów w grudniu 1939 r. do rozmów z niemiecką komendą obozu ${ }^{16}$. Ks. Tomiak pełnił dodatkowo funkcję dziekana grupy kapelanów z Rotenburga ${ }^{17}$.

Księża kapelani, którzy patrzą na nas z fotografii, pełnili odpowiedzialne funkcje w czasie kampanii wrześniowej. Widzimy dziekana Marynarki Wojennej (Miegoń), dziekanów armii „Poznan” (Tomiak), „Warszawa-odcinek „Warszawa wschód” (Turzyński), „Warszawa-odcinek „Warszawa zachód” (Ziemiański), „Łódź” i Obrony Warszawy (Rojek). W obozie przebywał również, jak już wspomniano, dziekan „Armii Kraków” (Truss). Dwóch z nich miało prawo nosić krzyż „Virtuti Militari”. Ks. Miegoń za zasługi w czasie wojny bolszewickiej, a ks. Rojek za postawę w czasie kampanii wrześniowej.

\section{Pytania i wątpliwości}

Wśród kapelanów z trzeciego rzędu znajduje się dwóch, co do których pojawiają się wątpliwości przy ich identyfikacji: Stefan Bujak (nr 4), Bączyński (nr 19). Zgodnie z ustaleniami zawartymi w Martyrologium ${ }^{18}$ zarówno Bujak, jak i Bączyński nie przebywali w Rotenburgu ${ }^{19}$. Kapelan $\mathrm{nr} 20$ (niezidentyfikowany) według Nuhna to prawdopodobnie ks. Otto Konrad. Natomiast ks. Rojek, który również nie był pewny jego personaliów, określa go jako: „wikariusz cyw.”. Z pewnością należy wykluczyć Otto Kristena (1887 lub 1889-1939) proboszcza WP, który zmarł we wrześniu $1939 \mathrm{r}^{20} \mathrm{Ks}$. Rojek wskazując na „dwudziestą osobę w trzecim rzędzie” jako: „ks. wikariusz cywilny - podpisał współpracę z Niemcami - wyjechał do Polski 1939" 21, twierdzi tym samym, że zdjęcie musiało być wykonane zaraz po przyjeździe księży polskich do Rotenburga, co miało miejsce

\footnotetext{
${ }^{16}$ Podlewski, Wierni Bogu, s. 278.

${ }^{17}$ APMAW, Ordynariat Biskupa Polowego Wojska Polskiego, Księża polscy w obozach jenieckich, Relacja Mariana Walczaka, Nasza niewola. Krótki zarys niewoli polskich XX. Kapelanów wojskowych w obozach koncentracyjnych w Niemczech, Dachau 8 V 1945.

${ }^{18}$ Por. Martyrologium, z. 4, s. 375.

${ }^{19}$ Męczennicy za wiarę 1939-1945, red. T. Kaczmarek i in., Warszawa 1996.

${ }^{20}$ Por. Kronika duszpasterstwa wojskowego, „Rozkaz Wewnętrzny”, 6 (1937) s. 258-259; T. Kryska-Karski, Duchowieństwo wojskowe II Rzeczypospolitej, Londyn 2000, s. 6; Wysocki, Kapelani, s. 599.

${ }^{21}$ Nuhn nie był pewien tożsamości tego księdza, przypuszczając, że mógł nim być niejaki „Konrad Otto”.
} 
w grudniu 1939 r. Innego zdania jest Nuhn, który uważa, że fotografia powstała w marcu 1940 r. Jego przypuszczenie potwierdzałoby zdanie ks. Rojka skierowane do gen. Kopańskiego w cytowanym już dokumencie: „Fotografia ta, została wykonana w obozie jenieckim Rottenburg/Fulda, na kilka dni przed wywiezieniem grupy do Buchenwaldu"22.

Fotografia została wykonana na tle budynku szkoły znajdującej się w Rotenburgu Jacob Grimm Schule ${ }^{23}$. Pod koniec sierpnia 1939 r., tuż przed wybuchem II wojny światowej w budynku szkolnym powstał szpital wojskowy. Od 1 grudnia 1939 r. budynek został przekształcony na obóz jeniecki dla ponad 400 polskich oficerów i kilkudziesięciu polskich kapelanów wojskowych.

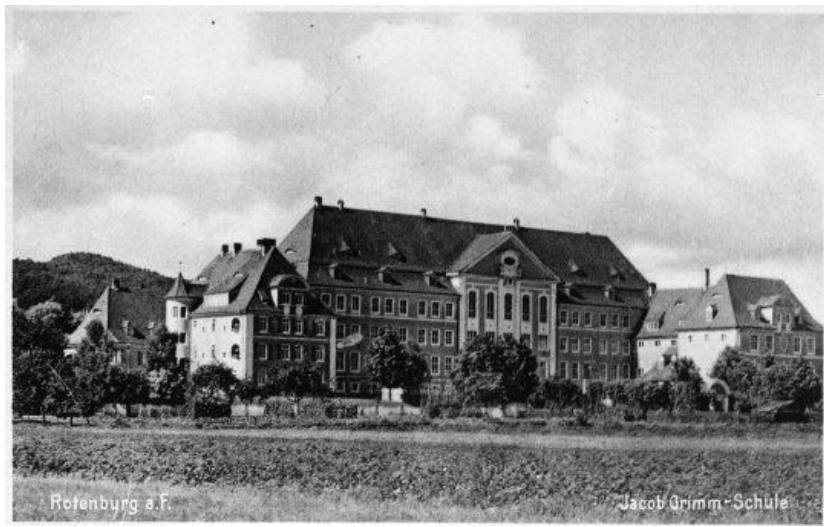

Il. 2. Jacob Grimm Schule, pocztówka z ok. $1930 \mathrm{r}$.

Źródło: Ze zbiorów: https://natlib.govt.nz/records/22613637 (dostęp: 28.12.2020).

Dnia 18 kwietnia 1940 r. zastępca komendanta ${ }^{24}$ oflagu w Rotenburgu zebrał wszystkich księży i w jednym z pomieszczeń przekazał ich do dyspozycji gestapo. Po załatwieniu formalności, sporządzeniu spisów, przy czym nie pozwolono pożegnać się z pozostałymi kolegami oficerami (była tam grupa 500 oficerów zabranych już z domów w kraju, przeważnie z grupy Modlin - zwolnionych po kapitulacji Warszawy), w eskorcie gestapowców zostali załadowani na kryte samochody i przewiezieni do obozu koncentracyjnego w Buchenwaldzie ${ }^{25}$. Czynem tym niemieckie władze wojskowe łamały postanowienia konwencji haskiej podpisanej 27 lipca 1929 r. w kwestii traktowania jeńców, nie przestrzegały też wła-

${ }^{22}$ APMAW, Duszpasterstwo polskie w Niemczech, Księża polscy w obozach jenieckich, A. Rojek, Fotografia Ks. Kapelanów Kampanii Wrześniowej 1939 roku wedlug szeregów, liczac od strony lewej, Londyn 29 II 1948.

${ }^{23}$ Oflag IX A/Z w Rotenburgu nad Fuldą; por. Jacob Green Schule, www.jgs-rof.de (dostęp: 28.12.2020).

${ }^{24}$ Ks. Rojek określa jego funkcję jako ,adiunkt”. APMAW, Ordynariat Biskupa Polowego Wojska Polskiego, Duszpasterstwo polskie w Niemczech, Księża polscy w obozach jenieckich, Rojek do Kopańskiego, Londyn 29 II 1948.

${ }^{25}$ Tamże. 
snych ustaleń dotyczących służby wojskowej kapelanów wojskowych oraz duchownych powołanych do służby na czas wojny ${ }^{26}$.

Zakres posług duszpasterskich i status kapelanów przebywających w niewoli władze niemieckie uregulowały dodatkowymi przepisami wewnętrznymi, które nie uwzględniały prawa międzynarodowego ${ }^{27}$.

Obóz w Buchenwaldzie należał do pierwszych niemieckich obozów koncentracyjnych zbudowanych przez nazistów po przejęciu władzy w 1933 r. Budowa obozu, zaplanowanego w pobliżu Weimaru na wzgórzu Etterberg, została zainicjowana w 1936 r. przez inspektora obozów koncentracyjnych i dowódcę oddziałów wartowniczych SS Totenkopf Theodora Eicke oraz namiestnika Rzeszy w Turyngii Fritza Sauckela. Pierwsi więźniowe trafili do niego na początku 1937 r. Przed wojną kierowano do niego kryminalistów, członków niemieckiego ruchu oporu, więźniów politycznych, a po 1937 r. Żydów. Po wybuchu wojny do Buchenwaldu kierowano byłych polskich powstańców i działaczy Związku Polaków w Niemczech. Do tego obozu trafili także polscy kapelani wojskowi, mimo że zgodnie z konwencją haską z 27 lipca 1929 r. powinni być oni traktowani jako jeńcy wojenni i przebywać w tzw. oflagach (Offizierslager für kriegsgefangene Offiziere). W Buchenwaldzie przebywali do początku lipca 1942 r., gdyż 7 lipca 1942 r. zostali przewiezieni do obozu koncentracyjnego w Dachau.

Podobnie jak Buchenwald obóz koncentracyjny w Dachau przed wybuchem wojny przeznaczony był do eliminowania z życia społecznego więźniów politycznych i innych kategorii przeciwników III Rzeszy na gruncie tzw. aresztu prewencyjnego (Schutzhaft, dosł. areszt ochronny), który stał się środkiem walki z opozycją polityczną. Po wybuchu II wojny światowej kierowano do niego wszystkich polskich duchownych, którzy zostali zatrzymani na terenach okupowanych i wcielonych do Rzeszy. Jesienią 1940 r. doszło do rozmów między rządem III Rzeszy a nuncjuszem papieskim w Berlinie Cesare Orsenigo na temat sytuacji księży katolickich w obozach koncentracyjnych. Wskutek interwencji Stolicy Apostolskiej strona niemiecka postanowiła przenieść wszystkich uwięzionych duchownych polskich do jednego obozu - Dachau. Notą werbalną z [23] listopada 1940 r. sekretarz stanu w Ministerstwie Spraw Zagranicznych Ernst von Weizsäcker poinformował nuncjusza Orsenigo, że zgodnie z decyzją Reichsführera SS i szefa policji niemieckiej w Ministerstwie Spraw Wewnętrznych Rzeszy duchowieństwo przebywające $w$ różnych obozach koncentracyjnych będzie teraz gromadzone w obozie koncentracyjnym w Dachau ${ }^{28}$. Okresowo przebywało tam od 20000 do 30000 więźniów, w tym ok. 2700 duchownych, stąd otrzymał on nawet nazwę „Priester-KZ”. Początkowo księża osadzeni w Dachau przebywali

${ }^{26}$ J. Güsgen, Die katholische Militärseelsorge in Deutschland zwischen 1920 und 1945, KölnWien 1989, s. 242.

${ }^{27}$ Por. N. Honka, Ślascy kapelani w obozach jenieckich, w: Wojskowa stużba śląskich duchownych w latach 1918-1980, red. J. Kapała, J. Myszor, Katowice 1990, s. 72.

${ }^{28}$ Verbalnote des Ausw. Amtes zu Nuntiatur Berlin [23] November 1940; Aufzeichnung Weizsäckers 28 XI 1940, Der Notenwechsel zwischen dem Heiligen Stuhl und der deutschen Reichsregierung. Bearbeitet von D. Albrecht, Bd. 3: Der Notenwechsel und die Demarchen des Nuntius Orsenigo 1933-1945, Bd. 3, Mainz 1980, s. 488-489. 
w zwykłych blokach i razem z innymi osadzonymi byli przydzielani do pracy w oddziałach. Duchowni tam umieszczeni, zgodnie z deklaracją władz niemieckich, mieli być zatrudnieni przy lekkich pracach fizycznych. W Dachau podobnie jak w Buchenwaldzie początkowo w wielkiej tajemnicy, później nawet na blokach z zachowaniem jednak ostrożności, zgromadzeni tam kapelanii polscy odprawiali nabożeństwa, w tym zwłaszcza mszę św. Po interwencji Stolicy Apostolscy duchowni tam zgromadzeni już oficjalnie mogli, jak się okazało tylko przez krótki czas, uczestniczyć we mszy św. ${ }^{29}$

Jedynie siedmiu z kapelanów uwiecznionych na fotografii w wyniku starań rodzin, znajomych, posiadanego obywatelstwa zostało zwolnionych z obozu przez Niemców (Drechny, Bujak, Gałat, Hübner, Krutkowski, Laboń). Jeden zginął w Buchenwaldzie (Drwal), 18 poniosło śmierć w Dachau (Belon, Brydacki, Dachtera, Francuz, Góralik, Jędrysik, Klarzak, Kryński, Lissowski, Michułka, Miegoń, Stopczak, Świderek, Syper, Tomiak, Zakrzewski, Zięba, Ziemiański). Dwóch z wymienionych: Dachtera i Miegoń w dniu 13 czerwca 1999 r. podczas mszy św. odprawianej w Warszawie zostało beatyfikowanych ${ }^{30}$. Prawdopodobnie 16 księży, którzy przeżyli wojnę powróciło do Polski (Bączyński, Drechny, Dymarski, Fiks, Grodecki, Hübner, Kamiński, Kańtoch, Konrad, Laboń, Maciejiczek, Pawłowski, Sokołowski, Szerlągowski (Szerląg), Turzyński, Bujak), 11 wyjechało do Wlk. Brytanii [Chowaniec, Czapski, Frąckowiak, Gołąb, Kornacki, Krutkowski, Krzyżanowski, Lewandowski (kilka miesięcy przed śmiercią wrócił do Polski), Stańczyk, Walczak, Żmikowski], trzech poświęciło się pracy duszpasterskiej w Argentynie: Gałat, Mielke, Gawędzki. Do USA wyjechało sześciu (Czach, Henryk, Fedorowicz, Rojek, Szacki, Wójcik). Jeden udał się do Kanady (Prusinowski), a jeden pozostał wśród Polaków w Niemczech (Janusz) ${ }^{31}$.

Spośród 55 kapelanów wojskowych zgromadzonych w Dachau 20 zmarło, a 32 doczekało się uwolnienia przez armię amerykańską w dniu 29 kwietnia $1945 \mathrm{r}^{32}$

${ }^{29}$ E. Thoma, Kreuz hinter Staheldraht, w: Die Geistlichen in Dachau sowie in anderen Konzentrationslagern und in Gefängnissen. Nachlaß von Pfarrer Emil Thoma. Erweitert und herausgegeben von Pfarrer E. Weiler, Mödling [1971], s. 832-839 (dalej: Weiler, Die Geistlichen).

${ }^{30}$ Męczennicy za wiare 1939-1945.

${ }^{31}$ Przyjmując za wiarygodne wiadomości ks. Rojka dotyczące pobytu księży Konrada, Maciejiczeka, Bujaka. Por. D. Bednarski, Biskup Józef Gawlina jako opiekun Polaków na emigracji, Katowice 2019; Honka, Śląscy kapelani w obozach jenieckich, s. 73.

${ }^{32}$ Weiler, Die Geistlichen, s. 64-65. 


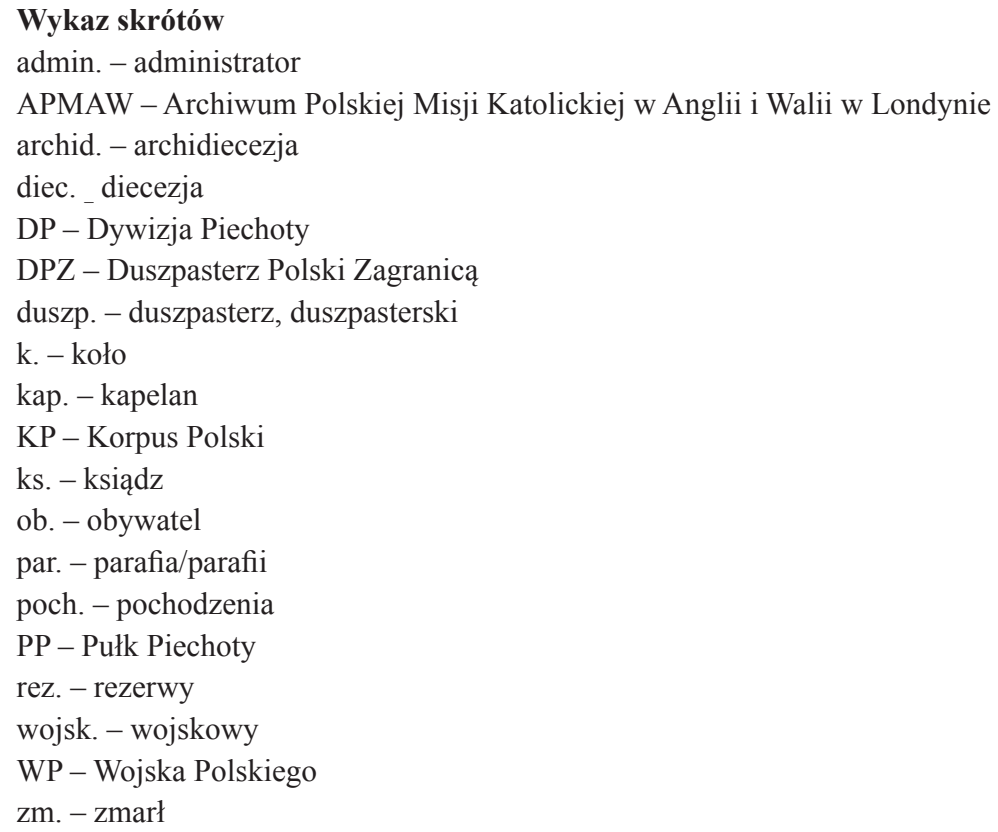

\section{Lista kapelanów Wojska Polskiego - jeńców w Rotenburgu, aresztach i obozach koncentracyjnych w czasie II wojny światowej}

Daty śmierci księży zmarłych w obozie w Dachau podano według ustaleń Thomy (Weilera), z korektami ustalonymi przez Jacewicza i Wosia w Martyrologium, uznając tym samym te źródła za najbardziej wiarygodne.

\section{Pierwszy rząd, od dołu, od lewej:}

1. Kazimierz Krzyżanowski (1906-1988), diec. płocka, kap. 67 PP, w niewoli od 18 IX; więzień w Łęczycy, Eichstätt, jeniec w Rotenburgu, więzień w Buchenwaldzie i Dachau. Po wojnie duszpasterz w Londynie i Nottingham, gdzie zm.

Zob.: Kryska-Karski, Duchowieństwo, s. 26; Wysocki, Kapelani, s. 601; Weiler, Die Geistlichen, s. 383; Podlewski, Wierni Bogu, s. 287.

2. Adolf Kryński (1905-1942), diec. siedlecka, kap. 34 PP, do niewoli dostał się 19 IX 1939, jeniec w Rotenburgu, więzień w Buchenwaldzie i Dachau, gdzie zm. 14 XI 1942.

Zob.: Wysocki, Kapelani, s. 600; E. Weiler, Die Geistlichen, s. 380; Podlewski, Wierni Bogu, s. 282; Martyrologium, z. 4, s. 356.

3. Franciszek Dachtera (1910-1944), archid. gnieźnieńska, kap. 62. PP Wielkopolskiej, w niewoli niemieckiej (od 17 IX 1939), jeniec w Rotenburgu, wię- 
zień w Buchenwaldzie (25 IV 1940) i Dachau (7 VII 1942), gdzie zm. 22 VIII 1944 na malarię jako ofiara doświadczeń medycznych.

Zob. Wysocki, Kapelani, s. 575; Weiler, Die Geistlichen, s. 190, Podlewski, Wierni Bogu, s. 281, 285; Martyrologium, z. 3, s. 19.

4. Michał Ziemiański (1895-1942), archidiec. krakowska, kap. 19. DP, brał udział w obronie Warszawy, (szef duszpasterstwa), jeniec w Hohnstein i Rotenburgu, więzień Buchenwaldu (18 IV 1940) i Dachau (7 VII 1942), gdzie zm. 15 XI 1942.

Zob. Wysocki, Kapelani, s. 550, 647; Weiler, Die Geistlichen, s. 737; Podlewski, Wierni Bogu, s. 283; Martyrologium, z. 3, s. 117-18.

5. Józef Gołąb (1911-2000), diec. włocławska, kap. 14. PP włocławski, pod Mełnem (k. Grudziądza) dostał się do niewoli (3 IX), przebywał w obozie Riesenburg, Linzu i Rotenburgu, więzień Buchenwaldu i Dachau. Po wojnie kap. obozu w Murnau, duszp. w Wlk. Brytanii, gdzie zm.

Zob. Wysocki, Kapelani, s. 584; Weiler, Die Geistlichen, s. 260; Podlewski, Wierni Bogu, s. 286; Martyrologium, z. 4, s. 453.

6. Marian Stańczyk (1908-), diec. łódzka, kap. 10 PP, do niewoli dostał się 19 IX 1939, jeniec w obozie w Sieradzu, Prenzlau, Rotenburgu, więzień w Buchenwaldzie i Dachau, po wyzwoleniu duszp. w Hohenfels i Murnau, następnie wyjechał do Włoch, później do W. Brytanii.

Zob. Wysocki, Kapelani, s. 628; Z. Turek, Spis księży pracujących w duszpasterstwie polskojęzycznym w Niemczech w latach 1945-2005, w: Duszpasterstwo polskojęzyczne w Niemczech 1945-2005, red. S. Bober, S. Budyń, Lublin-Hannover 2006, s. 483, Weiler, Die Geistlichen, s. 628; Podlewski, Wierni Bogu, s. 288.

7. Michał Drechny (ur. 1906 w Chicago), archidiec. krakowska, ob. amerykański poch. polskiego, kapitan rezerwy WP (1939), zmobilizowany i przydzielony do 3 Pułku Strzelców Podhalańskich 21 DP, jeniec w Stargardzie, Arnswald, Prenzlau (od 8 XII 1939), Rotenburg (24 XII 1939), więzień w Buchenwaldzie, skąd zwolniony (18 IV 1940) jako ob. USA. Po wojnie duszp. w polskich ośrodkach w Lubece, Hamburgu, Wentrof. W 1947 powrócił do Polski.

Zob. Wysocki, Kapelani, s. 576; Z. Turek, Spis księży, s. 405; S. Podlewski, Wierni Bogu, s. 290; https://archiwum-ordynariat.wp.mil.pl [A. Szutowicz, Los kapelanów Oflagu II B Arnswalde (Choszczno) na tle losu jeńców kapelanów Wojska Polskiego], (dostęp: 13.11.2020); Martyrologium, z. 3, s. 96.

8. Henryk Kornacki (1908-1956), diec. włocławska, kap. 25 DP w Armii Poznań, w niewoli niemieckiej (od 29 IX 1939), jeniec w Prenzlau, Murnau i Rotenburgu, więzień Buchenwaldu i Dachau. Odznaczony przez gen. Kutrzebę 
orderem Virtuti Militari. Po wojnie duszp. w Murnau, kap. w Armii Andersa, duszp. w Wlk. Brytanii. Zmarł w Londynie (19 I 1956).

Zob.: https://archiwum-ordynariat.wp.mil.pl (dostęp: 14.11.2020); Kryska-Karski, Duchowieństwo, s. 24; Wysocki, Kapelani, s. 596; Weiler, Die Geistlichen, s. 361; Turek, Spis księży, s. 434; Podlewski, Wierni Bogu, s. 286; Martyrologium, z. 4, s. 467-68.

\section{Drugi rząd, u dołu, od lewej}

1. Artur Wojciech Rojek (1906-1988), diec. przemyska, mjr, duszp. parafii wojsk. w Kaliszu, dziekan Armii „Łódź”, dziekan Obrony Warszawy. Za kampanię wrześniową odznaczony krzyżem Virtuti Militari, jeniec w Königstein (za domaganie się możliwości odprawienia mszy osadzony na 21 dni w bunkrze) i Rotenburgu, więzień w Buchenwaldzie (od 18 IV 1940) i Dachau (od 7 VII 1942). Po wojnie Naczelny Kapelan Obozów Rozmieszczenia II Korpusu Wojsk Polskich. Wyjechał do Londynu (1948), a następnie do USA (1949). Zmarł w Nowym Jorku (15 II 1988).

Zob. Kryska-Karski, Duchowieństwo, s. 37; Wysocki, Kapelani, s. 537, 558; 589, 623; Weiler, Die Geistlichen, s. 564-565; R. Nir, Śp. ks. prał. Artur W. Rojek (1906-1988). Wspomnienie, DPZ, R. 39 (1988), s. 489-492; Podlewski, Wierni Bogu, s. 287; Martyrologium, z. 4, s. $302-$ 303; biografia: http://www.gorzyce.itl.pl/j3/index.php/gmina/historia-gminy/postacie-historyczne/103-ks-dziekan-w-a-rojek, (dostęp: 30.12.2020).

2. Józef Czach (1888-1957), diec. przemyska, admin. par. wojsk. w Tarnopolu, Dubnie, szef duszp. 12 DP, w niewoli niemieckiej (od 10 IX 1939), jeniec w Görlitz, Prenzlau, Murnau i Rotenburgu, więzień w Buchenwaldzie i Dachau. Po wojnie duszp. Polaków w Kufstein, Bad Kohlgrub, Murnau, Altersdorf, Altenstadt, duszp. kombatantów polskich w USA,

Zob. Kryska-Karski, Duchowieństwo, s. 12; Wysocki, Kapelani, s. 573; Weiler, Die Geistlichen, s. 183; Turek, Spis księży, s. 401; Podlewski, Wierni Bogu, s. 284; Martyrologium, z. 4, s. 291.

3. Józef Milke (Mielke) (ur. 1900 ), archid. poznańska, kap. 57 PP, w niewoli po walkach nad Bzurą (21 IX), w obozach w Łęczycy, Eichstätt, Rotenburgu, więzień w Buchenwaldu i Dachau. Po wojnie w Argentynie.

Zob. Wysocki, Kapelani, s. 610; Weiler, Die Geistlichen, s. 455; Podlewski, Wierni Bogu, s. 287; Martyrologium, z. 4, s. 125.

4. Czesław Lissowski (1895-1942), diec. płocka, kap. 4 Pułku Strzelców Konnych, internowany w więzieniu w Łęczycy, oflagu w VII B w Eichstätt (od 15 X 1939) i Rotenburgu (od 9 XII 1939), więzień w Buchenwaldzie (od 18 IV 1940) i Dachau (6-7 VII 1942), gdzie zm. 15 XI 1942.

Zob. Wysocki, Kapelani, s. 604; Weiler, Die Geistlichen, s. 414-15; Podlewski, Wierni Bogu, s. 282.

5. Józef Klarzak (Klarczak) (1887-1942), diec. częstochowska, kap. WP, więzień od 5 IX 1939 (Brennowo, Guttentag, Lamsdorf), jeniec w Itzehoe, Ro- 
tenburgu, więzień w Buchenwaldzie i Dachau (7 VII 1942), gdzie zm. 18 VIII 1942.

Zob. Wysocki, Kapelani, s. 594; Weiler, Die Geistlichen, s. 345; Martyrologium, z. 2, s. 149; Podlewski, Wierni Bogu, s. 27, 28.

6. Adolf Fedorowicz (ur. 1890), diec. mohylowska, adm. par. wojsk. w Stanisławowie, szef duszp. Podolskiej Brygady Kawalerii, od [września] 1939 w obozie w Braunschweig, jeniec w Rotenburgu, więzień w Buchenwaldzie i Dachau, poddawany doświadczeniom flegmony sztucznej. Po wojnie duszp. w Bad Kohlgrub, Murnau i Gauting, od 1951 w USA.

Zob. Turek, Spis księży, s. 408; Kryska-Karski, Duchowieństwo, s. 15; Wysocki, Kapelani, s. 579; Weiler, Die Geistlichen, s. 224; Podlewski, Wierni Bogu, s. 285; Martyrologium, z. 4, s. 11.

7. Józef Tomiak (1890-1942), archid. poznańska, ppłk, dziekan w Armii „Poznań”, jeniec w Murnau, Rotenburgu (od XII 1939), więzień w Buchenwaldzie (17 IV 1940) i Dachau, gdzie został zamordowany przez pielęgniarza 9 VIII 1942.

Zob. Kryska-Karski, Duchowieństwo, s. 4; Wysocki, Kapelani, s. 535, 636; Weiler, Die Geistlichen, s. 668; Podlewski, Wierni Bogu, s. 283; Martyrologium, z. 4, s. 170.

8. Andrzej Kamiński (1890-1965), ppłk, dziekan-szef duszp. 26 DP, w niewoli po bitwie pod Bzurą (19 IX), jeniec w Hohenstein (Oflag IVa, Rotenburgu, więzień Buchenwaldu (od 18 IV 1940) i Dachau. Po oswobodzeniu od 19 IX 1945 r. pracował w dekanacie 30 Korpusu jako duszpasterz polskiego ośrodka Maczków (Haren/Ems) oraz Wesuwe/Meppen,

Zob. Wysocki, Kapelani, s. 591; Weiler, Die Geistlichen, s. 333; Turek, Spis księży, s. 425; Podlewski, Wierni Bogu, s. 253, 254, 262, 266; Martyrologium, z. 3, s. 258.

9. Franciszek Dymarski (1901-1963), archid. poznańska, mjr, szef duszp. 14 DP, w niewoli niem. (od 19 IX 1939), jeniec w Murnau, Rotenburgu, więzień Buchenwaldu (od 8 XII 1939) oraz Dachau (od 7 VII 1942). Po wojnie wrócił do Polski.

Zob. Kryska-Karski, Duchowieństwo, s. 15; Wysocki, Kapelani, s. 578; M. Przybylski, Duszpasterstwo księży diecezjalnych oraz kapelanów wojskowych w latach 1919-1939 na terenie Okręgu Korpusu nr VII, Poznań 2014, s. 162; Weiler, Die Geistlichen, s. 215; Podlewski, Wierni Bogu, s. 99, 277-279, 285, 290; Martyrologium, z. 4, s. 62.

10. Franciszek Drwal (1907-1942), diec. tarnowska, kapitan rez. WP (od 1.I.1939), kap. wrześniowy w szpitalu polowym nr 30., jeniec w Arnswald, Weimar, Rotenburgu, więzień w Buchenwaldzie (od 8 IV 1940), gdzie zm. 1 VI 1942. Zob. https://archiwum-ordynariat.wp.mil.pl [P. Glugla, Kapelani wojskowi z diec. tarnowskiej], (dostęp: 13.11.2020); Wysocki, Kapelani, s. 576; Podlewski, Wierni Bogu, s. 279; Martyrologium, z. 4, s. 378. 
11. Stanisław Wójcik (1895 lub 1898-1980), diec. tarnowska, szef duszp. 9 DP „Siedlce”, w niewoli po kapitulacji Warszawy (od 29IX), jeniec w Braunschweigu, Hadamar, Rotenburgu, więzień w Buchenwaldzie i Dachau. Po wojnie kap. polskich żołnierzy w Anglii, od 1952 w USA.

Zob. https://archiwum-ordynariat.wp.mil.pl/pl (P. Glugla, Kapelani wojskowi z diecezji tarnowskiej; tegoż, Parafie wojskowe na terenie diecezji tarnowskiej w okresie II Rzeczypospolitej), (dostęp: 11.11.2020); Kryska-Karski, Duchowieństwo, s. 47; Weiler, Die Geistlichen, s. 715, Podlewski, Wierni Bogu, s. 289; Martyrologium, z. 4, s. 391.

12. Jan Michułka (1892-1942), diec. przemyska, kap. 19 PP, duszp. par. wojsk. w Włodzimierzu Wołyńskim i Stanisławowie, kap. 27 Dywizji Piechoty, jeniec w Rotenburgu, więzień w Buchenwaldzie (18 IV 1940) i Dachau (7 VII 1942), gdzie zm. 7 IX 1942 [wg Martyrologium (s. 299)].

Zob. Biała księga (dostęp: 12.12.2020); Kryska-Karski, Duchowieństwo, s. 31; Wysocki, Kapelani, s. 610; Weiler, Die Geistlichen, s. 456; Podlewski, Wierni Bogu, s. 282; Martyrologium, z. 4, s. 298 (tam Mihułka).

13. Stanisław Grodecki, archid. krakowska, kap. rez. 8 Pułku Ułanów, wzięty do niewoli pod Ulowem od 20 IX. Przeszedł areszty i obozy: Kraków, Stargard, Arnswalde k. Piły (Choszczno), Prenzlau, Rotenburg, Buchenwald i Dachau. Zob. Podlewski, Wierni Bogu, s. 286; Kryska-Karski, Duchowieństwo, s. 18; Weiler, Die Geistlichen, s. 274; Martyrologium, z. 3, s. 98; Wysocki, Kapelani, s. 585, (według autora było dwóch duchownych kapelanów o nazwisku Grodecki, obydwaj mieli się dostać do niewoli niemieckiej, przy czym żaden z nich nie przebywał w Rotenburgu).

\section{Trzeci od dołu, od lewej:}

1. Juliusz Janusz (1906-1978), diec. łucka, kap. 45 Pułku Strzelców Kresowych, wzięty do niewoli pod Tomaszowem Maz. (11 IX 1939), więziony w Kozienicach, Radomiu, Kielcach, Görlitz, Prenzlau, jeniec w Rotenburgu (od 8 XII 1939), więzień w Buchenwaldzie (od 18 IV 1940) i Dachau (od 7 VII 1942), duszp. w Murnau, Mannheim, naczelny kap. Polskich Kompanii Wartowniczych przy armii ameryk., budowniczy domu dziecka ,Marianum” w Carlsbergu, członek Komisji Episkopatu Polski ds. Duszp. Polonii Zagr. (od 1975). Zmarł w Mannheim.

Zob. Turek, Spis księży, s. 420; Wysocki, Kapelani, s. 589; Weiler, Die Geistlichen, s. 312; Szymański, Duszpasterze Polonii, t. 1, s. 63-64; Podlewski, Wierni Bogu, s. 286; Martyrologium, z. 4, s. 257.

2. Władysław Miegoń (1892-1942), diec. sandomierska, dziekan Marynarki Wojennej, odznaczony krzyżem Virtuti Militari IV kl. (1922), kap. Dowództwa Floty w Gdyni (1934), uczestniczył w walkach na Wybrzeżu, jeniec w Szlezwik-Holsztynie i Rotenburgu, więzień w Buchenwaldzie (18 IV 1940) i Dachau (od 8 VII 1942), gdzie zm. 15 X 1942. 
Zob. http://wojskowagdynia.parafia.info.pl/?p=main\&what=25 (dostęp: 14.11.2020); B. Szwedo, Zawsze w pierwszej linii: kaplani odznaczeni Orderem Virtuti Militari 1914-1921, 19391945, Warszawa 2004, s. 88-91; Wysocki, Kapelani, s. 540, 610; Weiler, Die Geistlichen, s. 456; Podlewski, Wierni Bogu, s. 282; Martyrologium, z. 4, s. 332.

3. Józef Laboń (1904-), ks. z Karsina (1931), prob. w Chylonii, więzień w Stargardzie Szczecińskim, jeniec w Rotenburgu, więzień w Buchenwaldzie (od 18 IV 1940). Zwolniony z obozu (8 VII 1941), powrócił do parafii św. Mikołaja.

Zob. Arolsen Archives, Concentration Camp Buchenwald, nr 1735205, „Józef Laboń”, https:// arolsen-archives.org, (dostęp: 17.11.2020); M. Gawron, Martyrologia, s. 28.

4. Jak podaje Nuhn duchownym tym mógł być Stefan Bujak ,,ksiądz z Brunszwiku'33", który w Rotenburgu przebywał do VI 1940; natomiast ks. Rojek pisze: „ks. wikariusz cywilny - nazwiska nie pamiętam - jest w Polsce”. Nie udało się ustalić bliższych danych personalnych.

5. Marian Walczak (1907-1970), archid. poznańska, kap. 1 Pułku Strzelców Konnych, wzięty do niewoli 18 IX 1939, jeniec w Murnau, Rotenburgu, więzień w Buchenwaldzie i Dachau. Po wojnie kap. w II Korpusie, zm. w Londynie (6 VI 1970).

Zob. M. Walczak, [Relacja, Nasza niewola], APMAW, Nasza niewola; Kryska-Karski, Duchowieństwo, s. 44; Wysocki, Kapelani, s. 638; Weiler, Die Geistlichen, s. 689; Podlewski, Wierni Bogu, s. 289; Martyrologium, z. 4, s. 173-174.

6. Jerzy Szacki (1884-1957), diec. pińska, kap. garnizonu w Inowrocławiu (1923-24), szef kierownictwa rejonu duszp. w Równem, duszp. w par. wojsk. Równem, na Oksywiu (Gdynia), Bydgoszczy, po napaści niemieckiej szef duszpasterstwa 15 Wielkopolskiej DP, uczestnik bitwy nad Bzurą i obrony Warszawy, jeniec w Braunschweig, Königstein, Rotenburgu, więzień w Buchenwaldzie i Dachau. Po wojnie duszp. w Murnau, Altenstadt oraz Ingolstadt. Od 1951 w USA, gdzie zm. w 1957.

Zob. Turek, Spis księży, s. 486; Wysocki, Kapelani, s. 631; Weiler, Die Geistlichen, s. 650; Podlewski, Wierni Bogu, s. 289.

7. Ludwik Żmijkowski (Zmikowski) (1901-1947), diec. łucka, duszp. par. wojsk. w Łomży, kap. 18 DP, w niewoli od 13 IX, jeniec w Kleideksen, Riesenberg, Lienz, Rotenburgu, więzień w Buchenwaldzie i Dachau. Po wojnie kap. w 2 Korpusie Polskim.

Zob. Kryska-Karski, Duchowieństwo, s. 49; Wysocki, Kapelani, s. 648; Weiler, Die Geistlichen, s. 741; Podlewski, Wierni Bogu, s. 289.

8. Denis Henryk (ur. 1909-), diec. sandomierska, kap. rez. 37 PP (od 1 I 1939). W niewoli niemieckiej (od 8 IX), jeniec w Hansdorf, Rotenburgu, więzień

${ }^{33}$ Niem. Braunschweig. 
w Buchenwaldzie (od 18 IV 1940) i Dachau (od 6 VII 1942). Po wojnie wyjechał do USA, gdzie w par. St. Germanus Parish in Arapahoe (Nebraska) wybudował kościół MB Fatimskiej i Golgotę jako wotum za ocalenie.

Zob. Wysocki, Kapelani, s. 576, Weiler, Die Geistlichen, s. 197; https://www.lincolndiocese. org/news/diocesan-news/8992-fatima-centennial-to-be-celebrated-at-arapahoe-parish-shrine (dostęp: 12.11.2020), Podlewski, Wierni Bogu, s. 285; Martyrologium, z. 4, s. 324.

9. Wojciech Zięba (1896-1943), diec. tarnowska, kap. 19 DP, jeniec w Rotenburgu, więzień w Buchenwaldzie (od 18 IV 1940) i Dachau (od 7 VII 1942), gdzie zm. 5 I 1943.

Zob. Kryska-Karski, Duchowieństwo, s. 49; https://archiwum-ordynariat.wp.mil.pl [biogram, oprac. P. Glugla], (dostęp: 14.11.2020); Weiler, Die Geistlichen, s. 734; Podlewski, Wierni Bogu, s. 284.

10. Józef Maciejiczek (1910-), ksiądz z Trzyńca (Zaolzie), kap. rez. WP, w niewoli od 1 IX 1939, jeniec w Itzenhoe (17 IX), Rotenburgu (8 XII), więzień w Buchenwaldzie (18 IV 1940) i Dachau (7 VII 1942), doczekał się wyzwolenia.

Zob. D. Bednarski, Martyrologium polskiego duchowieństwa z Zaolzia podczas II wojny światowej, „Śląskie Studia Historyczno-Teologiczne”, 48(1) (2015), s. 64, 80; Weiler, Die Geistlichen, s. 423; Podlewski, Wierni Bogu, s. 287; Wysocki, Kapelani, s. 605-606; Martyrologium, z. 3, s. 191, Honka, Śląscy kapelani w obozach jenieckich, s. 72.

11. Roman Fiks (1896-1988), archid. warszawska, kap. 45 PP, wzięty do niewoli 30 IX 1939, jeniec w Braunschweig, Hadamar, Rotenburg, więzień w Buchenwaldzie i Dachau. Po wojnie kap. w 2 Korpusie Polskim, w 1947 powrócił do Polski.

Zob. Wysocki, Kapelani, s. 579; Kryska-Karski, Duchowieństwo, s. 15; Weiler, Die Geistlichen, s. 228; Podlewski, Wierni Bogu, s. 285; Martyrologium, z. 2, s. 354.

12. Jan Zakrzewski (1908-1942), diec. siedlecka, kap. 26 Pułku Ułanów, jeniec w Rotenburgu, więzień w Buchenwaldzie (od 18 IV 1940) i Dachau (od 7 VII 1942), gdzie zm. 15 VIII 1942.

Zob. Wysocki, Kapelani, s. 644, Weiler, Die Geistlichen, s. 725, Podlewski, Wierni Bogu, s. 283.

13. Ludwik Brydacki(1894-1942), diec. sandomierska, kap. wojsk. wŁomży i Mołodeczynie, kap. 86. PP (od VIII 1939), uczestnik walk w okolicach Piotrkowa Tryb., jeniec w Rotenburgu, więzień Buchenwaldu (od 18 IV 1940) i Dachau (od 6 VII 1942), gdzie zm. 3 X 1942.

Zob. Kryska-Karski, Duchowieństwo, s. 10; Wysocki, Kapelani, s. 569; Weiler, Die Geistlichen, s. 154; Podlewski, Wierni Bogu, s. 280-281; Martyrologium, z. 4, s. 323.

14. Aleksander Szerlągowski (Szerląg) (1894-1964), diec. przemyska, kap. szpitala polowego we Lwowie, jeniec w Lamsdorfie, Rotenburgu, więzień w Bu 
chenwaldzie i Dachau. Po wojnie duszp. w Hohenfels oraz w Misji Watykańskiej, powrócił do Polski; duszp. w Dębowcu.

Zob. Kryska-Karski, Duchowieństwo, s. 42; Turek, Spis księży, s. 487; Wysocki, Kapelani, s. 631-632; Weiler, Die Geistlichen, s. 654; Podlewski, Wierni Bogu, s. 289; A. Szerlągowski, Z dziejów Dębowca, mps, Dębowiec 1952; Martyrologium, z. 4, s. 306.

15. Kazimierz Sokołowski (1894-1975), archid. gnieźnieńska, kap. 25 DP, kap. w szpitalu polowym nr 703; wzięty do niewoli pod Iławą, jeniec w Prenzlau, Rotenburgu, więzień w Buchenwaldzie i Dachau.

Zob. Kryska-Karski, Duchowieństwo, s. 40; Wysocki, Kapelani, s. 627; Weiler, Die Geistlichen, s. 616; Podlewski, Wierni Bogu, s. 288; Martyrologium, z. 3, s. 69.

16. Józef Gałat (1908-1967), kap. rez. szpitala polowego nr 202 (lub 301), w niewoli od 17 IX, jeniec w Prenzlau i Rotenburgu, więzień w Buchenwaldzie i Dachau (zwolniony 7 VII 1942), po wyzwoleniu w 2 KP, wyjechał do Argentyny, w 1957 wstąpił do paulinów w USA; zm. w Filadelfii (USA).

Zob. Kryska-Karski, Duchowieństwo, s. 16; Wysocki, Kapelani, s. 581; Weiler, Die Geistlichen, s. 242, (tu inna data zwolnienia 29 IV 1942); Turek, Spis księży, s. 410; Z. Werra, Działalność duszpasterska w 2. Korpusie Polskich Sit Zbrojnych na Zachodzie gen. Władystawa Andersa 1941-1947, Warszawa 2009, s. 230, 235, 236; Podlewski, Wierni Bogu, s. 290; Martyrologium, z. 3, s. 254.

17. Feliks Pawłowski (1875-1953), diec. przemyska, duszp. w Czyszkach, Nowosielcach, Kańczudze i Brzyskach, od 1937 na emeryturze w Krościenku. W czasie II wojny światowej jeniec w Rotenburgu, więzień w Auschwitz i Buchenwaldzie. Po wojnie duszp. w Ambergu, powrócił do Polski (1945), pochowany w Krościenku.

Zob. Arolsen Archives, Concentration Camp Buchenwald, nr 1735205, „Feliks Pawłowski”, https://arolsen-archives.org (dostęp: 17.11.2020); Turek, Spis księży, s. 463; S. Zych, Diecezja przemyska obrządku łacińskiego w warunkach okupacji niemieckiej i sowieckiej 19391944/1945, Przemyśl 2011, s. 210; Martyrologium, z. 4, s. 300.

18. Jan Francuz (1894-1942), diec. kielecka, kap. rez. (1 VI 1919), uczestnik wojny bolszewickiej (1920), w czasie kampanii wrześniowej przydzielony do 4. Szpitala Okręgowego w Łodzi, internowany na Węgrzech. Tam też zakładał organizacje charytatywne, działał w tamtejszym Katolickim Duszpasterstwie Polskim. Po nieudanej próbie powrotu do kraju (X 1939) jeniec w Rotenburgu, więzień Buchewaldu i Dachau (od 15 VII 1942), gdzie zm. 17 IX 1942.

Zob. S.M. Przybyszewski, Ks. mjr Jan Francuz, kap. dwóch wojen, męczennik (1920-1939), Busko Zdrój 2002; Weiler, Die Geistlichen, s. 235; Podlewski, Wierni Bogu, s. 281.

19. Jan Bączyński (1882-1947), diec. tarnowska, duszp. w Krościenku (19201947), dziekan łącki, areszt. wraz ze Stanisławem Bujakiem i Feliksem Pawłowskim, internowany do Niemiec (3 IX 1939-28 XI 1940) m.in. w obozach 
w Braunschweig, Dobiegniewie, Starogardzie, Ostrzeszowie i Rotenburgu.

Zob. A. Marczyński, Udziat duchowieństwa w walce z okupantem w Gorcach i Beskidach w latach 1939 do 1945, „Nasza Przeszłość”, 67 (1987), s. 202-203; Martyrologium, z. 4, s. 375 (brak informacji o pobycie w Rotenburgu!).

20. XX - niezidentyfikowany. Według H. Nuhna mógł być nim niejaki Otto Konrad. Natomiast ks. A. Rojek podaje: „wikariusz cyw.”. Nie udało się ustalić personaliów wspomnianego księdza. Z pewnością należy wykluczyć: Otto Kristena (1887 lub 1889-1939), proboszcza WP, zm. we wrześniu 1939.

Zob. Kronika duszpasterstwa wojskowego, Rozkaz Wewnętrzny, nr 6/1937, s. 258-259; Kryska-Karski, Duchowieństwo, s. 6; Wysocki, Kapelani, s. 599.

21. Walenty Turzyński (Turzyski) (1890-1969), diec. przemyska, duszp. parafii wojskowej w Stryju, szef duszp. 5 DP (Lwowska), walczył w obronie Warszawy, wzięty do niewoli 1 X, jeniec w Nienburgu (11 X 1939), Spittal n. Drau, Rotenburgu, więzień w Buchenwaldzie i Dachau. Po wojnie duszp. w Murnau, Altenstadt oraz Ingolstadt, powrócił do Polski (1947).

Zob. Kryska-Karski, Duchowieństwo, s. 44; Turek, Spis księży, s. 493; Wysocki, Kapelani, s. 550, 636; Weiler, Die Geistlichen, s. 675; Martyrologium, z. 4, s. 308.

22. Andrzej Gawędzki (1893-1977), diec. łomżyńska, duszp. w Augustowie i Łomży, Szczuczynie i Grajewie (1930-39), kap. 9 Pułku Strzelców Konnych, w niewoli niem. (od 6 X) jeniec w Murnau, Rotenburgu ( od XII 1939), więzień Buchenwaldu (IV 1940) i Dachau (VII 1942). Po wojnie kap. II Korpusu WP Duszp. w Argentynie (od 1947 aż do śmierci). Jego prochy spoczywają na Cmentarzu Bródnowskim.

Zob. Wysocki, Kapelani, s. 581; Weiler, Die Geistlichen, s. 248; Werra, Działalność duszpasterska, s. 230, 235, 236, 238; Podlewski, Wierni Bogu, s. 285-286; Martyrologium, z. 2, s. 177.

23. KazimierzKrutkowski(1903-),diec.siedlecka,duszp.wpar.wojskowejw Gnieźnie, szef duszp. w 17 DP, w niewoli od 22 IX, jeniec w Żyrardowie, Nienburgu, Spittalu/Drau, Rotenburgu, więzień w Buchenwaldzie i Dachau. Po wojnie duszp. w Murnau, potem w 2 KP.

Zob. Kryska-Karski, Duchowieństwo, s. 26; Wysocki, Kapelani, s. 600; Weiler, Die Geistlichen, s. 379; Turek, Spis księży, s. 439-440; Podlewski, Wierni Bogu, s. 290; Martyrologium, z. 4, s. $355-56$.

\section{Czwarty rząd, od dołu, od lewej:}

1. Władysław Świderek (1898-1942), diec. łódzka, kap. 1 batalionu 40 PP „Obrony Lwowa”. Brał udział w obronie Warszawy i Modlina, jeniec w Rotenburgu, więzień w Buchenwaldzie (od 18 IV 1940) i Dachau (od 7 VII 1942), gdzie zm. 25 VIII 1942.

Zob. https://archiwum-ordynariat.wp.mil.pl (biogram M. Ceglarek), (dostęp: 14.11.2020); Weiler, Die Geistlichen, s. 772; Podlewski, Wierni Bogu, s. 81, 84, 95, 101, 283. 
2. Seweryn Jędrysik (1893-1942), w 1921 wstąpił do dominikanów, św. kapł. w Rzymie, duszp. wojskowy w Słonimiu nad Szczarą (obecnie Białoruś), mjr, kap. 20 DP. Uczestnik walk w obronie Warszawy. Jeniec w Hohensteinie (od X 1939), Rotenburgu, więzień Buchenwaldu i Dachau (6 VII 1942), gdzie zm. 5 września 1942.

Zob. A. Wilgusiewicz, Seweryn Jędrysik (1893-1942), w: Tobie Polsko. Szkice biograficzne działaczy ruchu niepodległościowego na Górnym Ślasku, red. W. Lesiuk, W. Zieliński, OpoleKatowice 1981, s. 214-217; Z. Zarzycka, Jędrysik Seweryn Jędrysik Seweryn (hasło), w: Słownik biograficzny katolickiego duchowieństwa śląskiego XIX i XX wieku, red. M. Pater, Katowice 1996, s. 152-153; Wysocki, Kapelani, s. 590; Weiler, Die Geistlichen, s. 319.

3. Antoni Prusinowski (1909-1963), diec. włocławska, kap. 60 PP, brał udział w obronie Warszawy, odznaczony Krzyżem Walcznych, do niewoli niemieckiej dostał się 27 IX 1939; więzień w Łodzi, Oleśnicy i Torgau, jeniec w Colditz i Rotenburgu, więzień w Buchenwaldzie (od 18 IV 1940) i Dachau (7 VII 1942). Po wojnie duszp. w Niemczech i Francji, Anglii i Kanady.

Zob. J.J. Szymański, Duszpasterze Polonii i Polaków za granica, t. 2, Lublin 2011, s. 142-143; Kryska-Karski, Duchowieństwo, s. 37; Wysocki, Kapelani, s. 620; Weiler, Die Geistlichen, s. 541; Podlewski, Wierni Bogu, s. 287-288; Martyrologium, z. 4, s. 493.

4. Augustyn Kańtoch (1897-1978), diec. częstochowska, kap. 27 DP, jeniec w Brennowo, Dobrodzień, Itzehou, Rotenburgu, więzień w Buchenwaldzie i Dachau (od 7 VII 1942). Po wojnie powrócił do Polski.

Zob. J. Związek, Ks. Kańtoch (1897-1978), „Częstochowskie Wiadomości Diecezjalne”, 53 (1979), s. 104-107; Wysocki, Kapelani, s. 592; Weiler, Die Geistlichen, s. 335.

5. Stanisław Syper (1900-1942), diec. tarnowska, kap. rez. WP, kap. 7 PP Legionów, jeniec w Rotenburgu, więzień w Buchenwaldzie (od 18 IV 1940) i Dachau (od 7 VII 1942), gdzie zm. 25 VIII 1942.

Zob. https://archiwum-ordynariat.wp.mil.pl (biogram P. Glugla), (dostęp: 14.11.2020), Weiler, Die Geistlichen, s. 649; Podlewski, Wierni Bogu, s. 282-283; Martyrologium, z. 4, s. 389.

6. Leonard Czapski (1907-1986), diec. siedlecka, kap. wrześniowy we Flotylli Pińskiej, jeniec w Murnau, Rotenburgu, więzień w Buchenwaldzie i Dachau, po wyzwoleniu przebywał w Murnau, a następnie we Włoszech i Wlk. Brytanii.

Zob. Kryska-Karski, Duchowieństwo, s. 12; Wysocki, Kapelani, s. 574; Weiler, Die Geistlichen, s. 185; Turek, Spis księży, s. 402; Podlewski, Wierni Bogu, s. 285.

7. Edward Frąckowiak (1905-1974), archid. poznańska, proboszcz w Piłce (1938-39), wzięty do niewoli pod Kutnem, jeniec w Łęczycy, Eichstätt, Rotenburg, więzień w Buchenwaldzie i Dachau. Po wojnie osiedlił się w Leicester, duszp. w Anglii, tam też zm. i pochowany.

Zob. T. Kryska-Karski, Duchowieństwo, s. 16; J.W. Wysocki, Kapelani, s. 580; E. Weiler, Die Geistlichen, s. 234; S. Podlewski, Wierni Bogu, s. 285; Martyrologium, z. 4, s. 66. 
8. Michał Lewandowski (1909-1983), archid. lwowska, kap. 14 Pułku Ułanów Podkarpackich. Uczestnik bitwy pod Bzurą i obrony Warszawy. Jeniec w Braun -schweig, Dietz, Hadamer, Rotenburgu, więzień w Buchenwaldzie i Dachau (od VII 1942). Po wojnie kap. 2 Warszawskiej Dywizji Pancernej PSZ, duszp. w Wlk. Brytanii. W 1983 z powodu złego stanu zdrowia wrócił do Polski, gdzie zmarł.

Zob. Kryska-Karski, Duchowieństwo, s. 27; Wysocki, Kapelani, s. 603; Weiler, Die Geistlichen, s. 411; Podlewski, Wierni Bogu, s. 100, 287; Martyrologium, z. 3, s. 135.

9. Ernest Chowaniec (1906-1984), archid. lwowska, kap. 22. Pułku Ułanów Podkarpackich, udział w obronie linii Warty, kap. Grupy Kawalerii „Chełm”, jeniec w Częstochowie, Görlitz, Prenzlau (do XII 1939), Rotenburgu (do 18 IV 1940), więzień Buchenwaldu i Dachau (od 7 VII 1942). Po wojnie duszp. Polaków w Füssen k. Murnau (od 7 VI 1945), następnie w II Korpusie we Włoszech skąd wyjechał do Palestyny (prefekt w Junackiej Szkole Kadetów w Beit-Nabala), od 1947 w duszp. polskim w Wlk. Brytanii.

Zob.: B. Szwedo, Zawsze w pierwszej linii: kapłani odznaczeni Orderem Virtuti Militari 19141921, 1939-1945, Warszawa 2004, s. 11; Kryska-Karski, Duchowieństwo, s. 11; Wysocki, Kapelani, s. 570; E. Weiler, Die Geistlichen, s. 172; Podlewski, Wierni Bogu, s. 284; Martyrologium, z. 3, s. 129.

10. Zdzisław Belon (1906-1942), diec. katowicka, kap. 4. Pułku Strzelców Podhalańskich (od 24 VIII 1939), w niewoli niemieckiej (od 19 IX), jeniec w Rotenburgu, następnie w Buchenwaldzie (od 18 IV 1940) i Dachau (od 7 VII 1942), gdzie zm. 27 IX 1942.

Zob. J. Myszor, Słownik biograficzny duchowieństwa (archi)diecezji katowickiej 1922-2008, red. J. Myszor, Katowice 2009, s. 20; Wysocki, Kapelani, s. 566; Weiler, Die Geistlichen, s. 127; Podlewski, Wierni Bogu, s. 280; Martyrologium, z. 3, s. 166.

11. Marian Stopczak (1904-1942), archid. krakowska, kap. 6 DP, jeniec w Rotenburgu, więzień w Buchenwaldzie (od 18 IV 1940) i Dachau (7 VII 1942), gdzie zm. 19 XI 1942.

Zob. Zeller, La Baraque, s. 278; Weiler, Die Geistlichen, s. 637; Wysocki, Kapelani, s. 630; Podlewski, Wierni Bogu, s. 282.

12. Jan Góralik (1889-1942), archid. krakowska, kap. rez. WP, duszp. w Radziechowach, Rychwałdzie, Cięcinie, Krakowie, Podwilku, dziekan Orawy. Oskarżony o podżeganie do zabójstwa niemieckiego oficera, areszt. wraz ze swym wikarym ks. Hübnerem, jeniec w Rotenburgu (od 8 XII 1939), więzień w Buchenwaldzie (18 IV 1940) i Dachau (7 VII 1942) gdzie zm. 26 X 1942.

Zob. Ł. Wiater, Ks. Jan Góralik - Kapłan, Społecznik, Męczennik, Nowy Targ 2016 [Arch. Ośrodka Karta, sygn. HB11/0043-I-07]; tenże, Nie bądź odważny w języku a gnuśny i leniwy $i$ swych czynach. Przykład życia księdza Jana Góralika; Weiler, Die Geistlichen, s. 263; Z. Waszkiewicz, Duszpasterstwo w siłach zbrojnych Drugiej Rzeczypospolitej (1918-1939), Toruń 2000, s. 268; Podlewski, Wierni Bogu, s. 286. 
13. Henryk Hübner (1913-1980), archid. krakowska, kap. rez. WP, areszt. wraz ze swoim prob. (ks. Jan Góralik), jeniec w Rotenburgu (od 8 XII 1939), więzień obozu w Buchenwald (18 IV 1940). Według Rojka Hübner został uwolniony w 1940, natomiast $Ł$. Wiater uznał jako prawdziwą informację podaną przez samego Hübnera, że zwolniony został 10 III 1942. Do końca wojny w Żywcu $\mathrm{z}$ zakazem pełnienia posługi duszp. pracował $\mathrm{w}$ hurtowni tytoniu i rozlewni octu.

Zob. Ł. Wiater, Nie bądź odważny w języku a gnuśny w swych czynach. Przykład życia księdza Jana Góralika, Archiwum Ośrodka KARTA, sygn. HB11/0043-I/07, s. 20; Martyrologium, z. 3, s. 100 (tam data zwolnienia: 10 III 1942).

\section{REFERENCES / BIBLIOGRAFIA}

\section{Źródła}

Archiwum Polskiej Misji Katolickiej w Anglii i Walii (APMAW)

Ordynariat Biskupa Polowego Wojska Polskiego

Duszpasterstwo polskie w Niemczech, Księża polscy w obozach jenieckich, bez sygnatury.

Arolsen Archives

[Międzynarodowe Centrum badań nad Prześladowaniami Nazistowskimi], Concentration Camp Buchenwald (https://arolsen-archives.org, dostęp: 17.11.2020).

Der Notenwechsel zwischen dem Heiligen Stuhl und der deutschen Reichsregierung. Bearbeitet von D. Albrecht, Bd. 3: Der Notenwechsel und die Demarchen des Nuntius Orsenigo 1933-1945, Bd. 3, Mainz 1980.

\section{Opracowania}

Adamska Jolanta, Sziling Jan, Polscy księża w niemieckich obozach koncentracyjnych, Warszawa 2007.

B.a., Apel do Księży bytych Kapelanów Wojska Polskiego w sprawie pomocy do opracowania Historii Duszpasterstwa w P.S.Z. podczas Drugiej Wojny Światowej 19391945, „Duszpasterz Polski Zagranicą”, 4-6 (1953) nr 2, s. 121-124.

Barzycka-Paździor Agata, Fotografia jako źródło historyczne: wybrane problemy, „Historyka: studia metodologiczne", 36 (2006) s. 105-117.

Bednarski Damian, Martyrologium polskiego duchowieństwa z Zaolzia podczas II wojny światowej, „Śląskie Studia Historyczno-Teologiczne”, 48(1) (2015) s. 61-86.

Bednarski Damian, Biskup Józef Gawlina jako opiekun Polaków na emigracji, Katowice 2019.

Gawron Mirosław, Martyrologia kapłanów diecezjalnych i zakonnych z Gdyni w latach 1939-1945, Gdynia 2017.

Güsgen Johannsen, Die katholische Militärseelsorge in Deutschland zwischen 1920 und 1945, Köln-Wien 1989.

Honka Norbert, Ślascy kapelani w obozach jenieckich, w: Wojskowa stużba ślaskich duchownych w latach 1918-1980, red. J. Kapała, J. Myszor, Katowice 1990, s. 71-78. 
Kowalska Jadwiga, Ordynariat biskupa Polowego Wojska Polskiego w Archiwum Polskiej misji Katolickiej w Anglii i Walii, w: Arcybiskup Józef Gawlina. Biskup polowy wojska Polskiego, red. A. Siomkajło, Londyn 2015, s. 33-42.

Kryska-Karski Tadeusz, Duchowieństwo wojskowe II Rzeczypospolitej, Londyn 2000.

[Kuria diecezja w Łodzi], Spis duchowieństwa i parafij diecezji łódzkiej, Łódź 1937.

Marczyński Aleksander, Udział duchowieństwa w walce z okupantem w Gorcach i Beskidach w latach 1939 do 1945, „Nasza Przeszłość”, 67 (1987) s. 197-236.

Nir Roman, Śp. ks. prat. Artur W. Rojek (1906-1988). Wspomnienie, „Duszpasterz Polski Zagranicą", 39 (1988) s. 489-492.

Podlewski Stanisław, Wierni Bogu i Ojczyźnie. Duchowieństwo katolickie w walce o niepodległość Polski w II wojnie światowej, Warszawa 1985.

Przybylski Marek, Duszpasterstwo księży diecezjalnych oraz kapelanów wojskowych w latach 1919-1939 na terenie Okręu Korpusu nr VII, Poznań 2014.

Przybyszewski Stanisław M., Ks. mjr Jan Francuz, kapelan dwóch wojen, męczennik (1920-1939), Busko Zdrój 2002.

Rabiński Jarosław, Rzeczkowska Ewa, Kowalska Jadwiga (red.), Dziennik czynności Naczelnego Wodza gen. Władysława Sikorskiego, t. 1: 30 VIII 1939 - 31 VII 1940, Lublin 2016.

Słownik biograficzny duchowieństwa (archi)diecezji katowickiej 1922-2008, red. J. Myszor, Katowice 2009.

Szwedo Bogusław, Zawsze w pierwszej linii: kapłani odznaczeni Orderem Virtuti Militari 1914-1921, 1939-1945, Warszawa 2004.

Szymański Józef, Duszpasterze Polonii i Polaków za granica, t. 1, Lublin 2010.

Szymański Józef, Duszpasterze Polonii i Polaków za granica, t. 2, Lublin 2011.

Turek Zdzisław, Spis księży pracujących $w$ duszpasterstwie polskojęzycznym $w$ Niemczech w latach 1945-2005, w: Duszpasterstwo polskojęzyczne w Niemczech 1945-2005, red. S. Bober, S. Budyń, Lublin-Hannover 2006, s. 389-512.

Waszkiewicz Zofia, Duszpasterstwo w siłach zbrojnych Drugiej Rzeczypospolitej (19181939), Toruń 2000.

Weiler Eugen, Die Geistlichen in Dachau sowie in anderen Konzentrationslagern und in Gefängnissen. Nachlaß von Pfarrer Emil Thoma. Erweitert und herausgegeben von Pfarrer E. Weiler, Mödling [1971].

Werra Zbigniew, Działalność duszpasterska w 2. Korpusie Polskich Sił Zbrojnych na Zachodzie gen. Władysława Andersa 1941-1947, Warszawa 2009.

Wiater Łukasz, Ks. Jan Góralik - Kapłan, Społecznik, Męczennik, Nowy Targ 2016.

Wilgusiewicz Antoni, Seweryn Jędrysik (1893-1942), w: Tobie Polsko. Szkice biograficzne działaczy ruchu niepodległościowego na Górnym Ślasku, red. W. Lesiuk, W. Zieliński, Opole-Katowice 1981, s. 214-217.

Wlaźlak Władysław P., Duszpasterstwo wojskowe $w$ diecezji częstochowskiej, „Ziemia Częstochowska", 32 (2005) s. 1-19.

Woś Jan, Jacewicz Wiktor, Martyrologium polskiego duchowieństwa rzymskokatolickiego pod okupacja hitlerowska w latach 1939-1945, z. 1-4, Warszawa 1977-1978.

Wysocki Wiesław J. (red.), Kapelani wrześniowi: stużba duszpasterska w Wojsku Polskim w 1939 r.: dokumenty, relacje, opracowania, Warszawa 2001.

Zarzycka Zyta, Jędrysik Seweryn (hasło), w: Słownik biograficzny katolickiego duchowieństwa ślaskiego XIX i XX wieku, red. M. Pater, Katowice 1996, s. 152-153.

Zeller Guillaume, La Baraque des prêtres, Dachau 1938-1945, Paris 2015.

Związek Jan, Ks. Kańtoch Augustyn (1897-1978), „Częstochowskie Wiadomości Diecezjalne", 53 (1979) s. 104-107. 
Zych Sławomir, Diecezja przemyska obrzadku łacińskiego w warunkach okupacji niemieckiej i sowieckiej 1939-1944/1945, Przemyśl 2011.

\title{
Netografia
}

Parafia Wojskowa Marynarki Wojennej RP w Gdyni-Oksywiu, http://wojskowagdynia. parafia.info.pl.

Ordynariat Polowy w Polsce, http://archiwum-ordynariat.wp.mil.pl.

Diecezja Lincoln, https://www.lincolndiocese.org/news/diocesan-news/8992-fatima-centennial-to-be-celebrated-at-arapahoe-parish-shrine.

National Library, Nowa Zelandia, https://natlib.govt.nz/.

Concentration Camp Buchenwald, https://arolsen-archives.org.

Gmina Gorzyce, http://www.gorzyce.itl.pl/j3/index.php/gmina/historia-gminy/postacie -historyczne/103-ks-dziekan-w-a-rojek.

\section{CHAPLAINS OF THE POLISH ARMY IN THE OFLAG IN ROTENBURG (DECEMBER 1939 - APRIL 1940) - THE STORY OF ONE PHOTOGRAPH}

\begin{abstract}
The authors, on the basis of a group photograph taken in Rotenburg, dated at the beginning of 1940, identify and present the war biographies of a company of chaplains in the Polish Army: prisoners of the oflag in Rotenburg an der Fulda, then prisoners of the concentration camp in Buchenwald and Dachau.

Keywords: Military chaplains, prisoners of war, concentration camp prisoners, Rotenburg an der Fulda
\end{abstract}

